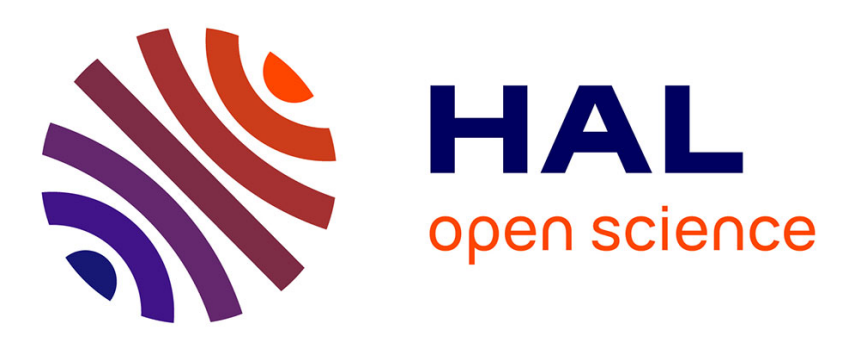

\title{
Perceptions of Demotion Decisions: A Social Capital Perspective
}

\author{
Sophie Hennekam, Steve Mckenna, Julia Richardson, Subramaniam
}

Ananthram

\section{- To cite this version:}

Sophie Hennekam, Steve Mckenna, Julia Richardson, Subramaniam Ananthram. Perceptions of Demotion Decisions: A Social Capital Perspective. European Management Journal, 2019, 37 (6), pp.730741. 10.1016/j.emj.2019.03.007 . hal-03232774

\section{HAL Id: hal-03232774 \\ https://hal.science/hal-03232774}

Submitted on 22 May 2021

HAL is a multi-disciplinary open access archive for the deposit and dissemination of scientific research documents, whether they are published or not. The documents may come from teaching and research institutions in France or abroad, or from public or private research centers.
L'archive ouverte pluridisciplinaire HAL, est destinée au dépôt et à la diffusion de documents scientifiques de niveau recherche, publiés ou non, émanant des établissements d'enseignement et de recherche français ou étrangers, des laboratoires publics ou privés. 
Article title : Perceptions of Demotion Decisions: A Social Capital Perspective

Authors and Affiliations : - Steve McKenna, Curtin University

-Julia Richardson, Curtin University

-Subramaniam Ananthram, Curtin University

Corresponding author : Sophie Hennekam, Audencia Business School 


\section{Article title: Perceptions of Demotion Decisions: A Social Capital Perspective}

Authors and affiliations:

Sophie Hennekam

Audencia Business School

IRGO Bordeaux

8 route de la Jonelière

35 Avenue d'Abadie

44312 Nantes

Bordeaux, France

shennekam@audencia.com

Steve McKenna

Curtin University

Perth, WA, Australia

s.mckenna@curtin.edu.au

Julia Richardson

Curtin University

Perth, WA, Australia

j.richardson@curtin.edu.au

Subramaniam Ananthram

Curtin University

Perth, WA, Australia

s.ananthram@curtin.edu.au

Corresponding author: Sophie Hennekam, shennekam@audencia.com
Abstract
This article examines how demotees and co-workers understand involuntary demotion decisions, using a social capital lens. Drawing on data based on semi-structured in-depth interviews from 23 demotees and 46 co-workers (two co-workers of each demoted worker), we find that the likelihood of being demoted is determined by several factors. The personal characteristics of the demotee influence three aspects of social capital: 1) the quality of the employee-management relationship, 2) the ability to socialise with other organizational members and 3) visibility in the organization. Our findings contribute to the relational embeddedness perspective of social capital as well the growing body of literature on the dark side of social capital in organizations by showing how a lack of social capital impacts on demotion decisions. Relevant implications for organizations and HR practitioners for utilizing demotion as a HR tool are discussed. 
Perceptions of Demotion Decisions: A Social Capital Perspective

Keywords:

Demotion, social capital, cultural capital, workplace relationships, socialization, visibility, decision-making, relational embeddedness, personal characteristics 


\section{Introduction}

There has been a longstanding interest in the impact of different types of capital on career experiences including opportunities for career advancement and objective and subjective career success (Richardson, Jogulu \& Rentschler, 2017; Kim, 2013). In career theory, social capital is understood as part of an individual's broader 'career capital' alongside their skills, competencies and motivations to pursue a particular career trajectory (Seibert, Kraimer \& Liden, 2001). While social capital has been associated with many positive outcomes for individuals in terms of their career experiences and opportunities (Kwon \& Adler, 2014), a more problematic 'darker side' has also been identified (Locke, 1999; Pillai, Hodgkinson, Kalyanaram \& Nair, 2017). It has been suggested that while certain types of social capital have career enhancing effects, others can be more limiting. While we know that building social capital in contexts that do not allow for individual growth or which may inhibit skill development may limit an individual's career trajectory (Arthur, Khapova \& Richardson, 2017), there is less understanding about the limiting effects of a lack of certain types of social capital. In this paper we argue that a lack of social capital can lead to a situation in which a career is negatively affected, for example, by being demoted. Positioning social capital as a relational phenomenon, this study aims to develop more insights on the influence of social capital (or the lack thereof) on career development. More precisely, we extend previous research by exploring involuntary downward career moves in the context of demotion. Demotion, defined as the reduction of an employee's rank and salary (van Dalen \& Henkens 2016; Verheyen, Deschacht \& Guerry, 2016), has received limited attention from career, HRM and management scholars more broadly. As a consequence, we know very little about how it is managed from either parties' perspective. Van Dalen and Henkens (2016) reported that while managers might consider demotion as a potential strategic HRM policy, they rarely 
apply it due to a lack of knowledge about its impact on subsequent performance and retention.

The limited attention paid to demotion among contemporary scholars and practitioners seems problematic given that according to some scholars, if managed correctly, it could be used as an alternative to terminating employment (Krause \& Semadeni, 2013). However, it could also lead to a wide range of negative individual and organizational outcomes including reduced levels of commitment, motivation, performance and increased turnover (Krause \& Semadeni, 2013; van Dalen \& Henkens, 2016). Recent research, for example, has found that the negative emotions and reactions from demotees can permeate through the organization affecting not only the demoted individual, but also their nondemoted colleagues (Hennekam, Ananathram \& McKenna, in press). Feelings of disillusion, uncertainty, vulnerability and anger have been reported amongst demotees and co-workers, triggering employee turnover (Hennekam et al., in press).

While there is an emerging body of literature examining the impact of demographic factors on demotion decisions, the impact of social capital and the interpersonal dimensions of demotion decisions are unclear. As a first step towards contributing to theoretical development in this domain and drawing on an in-depth qualitative study, we aim to theorise demotees' and co-workers' understandings of how and why demotion decisions are made. Locating the study within social constructivism centres attention on how study participants construe and interpret demotion decisions. A key element of this approach is a "focus on interaction and social practices" (Burr, 2003, p. 4). What happens between people, their interactions and relations, are important in generating knowledge about how the world operates and how versions of knowledge and 'truth' are constructed (Burr, 2003). This is particularly important in this study where we are concerned with how demotees and their co- 
workers perceive demotion decisions in the context of organizational interactions and relations.

As social capital theory has been shown to be a useful theoretical framework in studying career advancement, we considered this a potentially useful lens through which to theorise demotion decisions (Bozionelos, 2015; Edelman, Bresnen, Newell, Scarbrough \& Swan, 2004), leading to the following research questions:

- What are the key social capital themes in demotees' understanding of demotion decisions?

- Are these themes congruent with their co-workers' understanding of the respective demotion decision?

\section{Literature Review}

\subsection{Demotion}

There is currently only limited understanding of demotion as an organizational phenomenon. The emerging literature on demotion suggests that a number of factors influence whether or not it is utilized. For example, in small organizations, it is unlikely to be used because of fixed personnel structures (Van Dalen \& Henkens, 2016; Verheyen et al., 2016). Economic climate and unemployment rates are also likely to influence whether organizations demote employees or terminate their employment altogether (Dohmen, Kriechel \& Pfann, 2004). Demographic factors may also impact decisions about who is demoted-where the chance of being demoted decreases with age but is higher for individuals with lower levels of education (Kooij, Guest, Clinton, Knight, Jansen and Dikkers, 2013; Verheyen et al., 2016). Women are also more likely to be demoted than their male counterparts; although this is related to the type of demotion used. For example, Verheyen et al. (2016) distinguished between job level, 
salary and job authority demotions and found that women are more likely to experience job authority demotion than their male counterparts in equivalent roles.

Whereas there is only limited research on demotion, there is a general consensus that demoting employees is likely to have negative organizational consequences. It can be perceived as reflecting a breach of trust, leading to increased turnover and/or reduced motivation and commitment (Van Dalen \& Henkens, 2016). It could also negatively impact on demotees' co-workers. Indeed, early research in labour economics suggests that individuals may leave an organization if they suspect that they are going to be demoted in order to protect their professional reputation (MacLeod \& Malcomson, 1988). The impact of demotion on individual behaviour is likely to be affected by whether the demotion was voluntary or involuntary. Individuals could choose to be demoted voluntarily in order to fulfil personal or professional needs (Verheyen \& Vermeir, 2011). Involuntary demotion, initiated by the organization (Carson \& Carson, 2007), could result in more negative outcomes for demotees, co-workers and the organization.

\subsection{Social Capital}

Social capital is defined as the product of investment strategies, individual or collective, consciously or unconsciously aimed at establishing or reproducing social relationships that are directly usable in the short or long term (Bourdieu, 2011: 84-85). Social capital is of strategic importance to individuals as it has been found to lead to positive outcomes (Kwon \& Adler, 2014). For example, having more social capital has been linked to higher compensation and more career success (Bozionelos, 2015; Richardson \& Kelliher, 2015), knowledge transfers and innovation (Maurer, Bartsch \& Ebers, 2011) as well as performance improvement (Moran 2005). However, scholars also increasingly acknowledge what has been understood as the 'dark side' of social capital (Edelman et al., 2004; Locke 1999) with 
corresponding negative outcomes (Adler \& Kwon 2002; Kwon \& Adler, 2014) such as barriers to learning, groupthink or the non-rational escalation of commitment, defined as the tendency to adhere to a particular course of action even in the face of negative information concerning the viability of that course of action (Staw, 1981). This negatively influences the quality of decision-making in organizations (Pillai et al., 2017) and may lead to a situation in which social relationships drive decision-making outcomes (Wang, McNally \& Lenihan, 2018).

We can distinguish between cognitive, structural and relational social capital (Nahapiet \& Ghoshal, 1998). The cognitive dimension refers to the resources that provide shared meaning and understanding between the network members (Nahapiet \& Ghoshal, 1998) and consists mainly of common values, shared goals and a shared vision (Inkpen \& Tsang, 2005). Structural embeddedness, defined as "the impersonal configuration of linkages between people or units" (Nahapiet \& Ghoshal, 1998: 244) is the idea that network structure alone needs to be considered in theorizing about social capital or in empirically exploring its consequences. In contrast to the 'impersonal' nature of structural embeddedness, relational embeddedness is defined as the "personal relationships people have developed with each other through a history of interactions" (Nahapiet \& Ghoshal, 1998: 244) and focuses on the quality of the relationship between individuals. Key aspects of relational embeddedness include interpersonal trust and trustworthiness, overlapping identities, and feelings of closeness or interpersonal solidarity. Although most previous research has focused on structural embeddedness, it has been argued that the effectiveness of social capital rests on more than just the structural configuration of an individual's network and researchers are increasingly acknowledging the importance of relational embeddedness (Elfenbein \& Zenger, 2014). For example, in knowledge transfer between subsidiaries (Ferraris, Santoro \& Scuotto, 2018), or as a substitute for the structural benefits of network closure in the case of network- 
bridging ties (Levin, Walter, Appleyard \& Cross, 2016). Also, relational capital has been found to be important in successful university-industry collaborations (Steinmo \& Rasmussen, 2018) and facilitates cross-border partnering (Meuleman, Jääskeläinen, Maula \& Wright, 2017).

In the present study, we consider how social capital embodies the form of a personal network of contacts affects demotion decisions by taking into account the quality of an individual's network relationships in organizations. We posit that certain types of social capital can not only enhance a career, as identified in previous studies (Kwon \& Adler, 2014), but can also give rise to demotion and thus inhibit career opportunities and experiences. More precisely, when an individual does not possess certain types of social capital, such as a positive relationships with their manager, or the ability to socialise effectively in an organizational context, it may lead to demotion.

\section{Method}

\subsection{Research context, sample and research design}

We considered a qualitative approach for this study to be appropriate as it has been argued that the relational embeddedness of social capital can be captured well by the use of qualitative methods (Dominguez \& Hollstein, 2014). This study was conducted in The Netherlands where Van Dalen \& Henkens (2014) found that $7 \%$ of businesses opted to use demotion. However, it is important to highlight that the prevalence of demotion is likely to be underestimated as it is often presented in more socially acceptable ways using terms like a 'career restructuring' or 'career switch' (Van Dalen \& Henkens, 2016). In addition, there are strict rules regarding the use of demotion. In many collective terms of employment, we can observe the so-called 80-90-100 rule which consists of a reduction of maximum $20 \%$ of the 
number of hours worked, while they keep $90 \%$ of their salaries and $100 \%$ of their pension (HR Kiosk the Netherlands, 2018). Moreover, demotion should not violate antidiscrimination regulations and when it is initiated by the employer it should be the consequence of changes in the workplace (such as a reorganization) and should be understood as being premised on "reasonable" grounds (HR Kiosk the Netherlands, 2018). This is similar to the laws and regulations in most European countries. We opted for a convenience and snow-ball sample by identifying people who had been demoted involuntarily by searching blogs and web-based forums. The use of social media to access research participants is especially helpful in accessing populations that are difficult to reach and in examining socially sensitive topics (Hennekam, 2016).

Those who responded to the invitation to participate were asked whether they knew other individuals who had experienced a demotion and who might be interested in contributing to the study. This technique is ideal for studying populations that are not easily accessible (O'Leary, 2004) and resulted in 23 interviews being conducted in phase 1 . In phase 2, we triangulated our findings by integrating the perceptions of interviewees' coworkers i.e. those who were not demoted themselves but had witnessed the demotion of someone else in the organization. The co-workers were identified by the demotees in phase 1 . We report here, therefore, on the findings from 46 interviews: 23 pairs. Table 1 outlines the demographics of both the demotees and the co-workers. Participants worked in diverse sectors, including financial services, education and healthcare. Moreover, the type of demotion, the official reason for the demotion and the self-reported reason for the demotion of the demotee by the co-workers are outlined in Table 1. Also, the self-described relationship of the co-workers with the demotee (distant vs close relationship) is provided. 
Table 2 provides the reasons that have led to the demotion. We distinguished between the official reason as put forward by the organization, the reason as perceived by the demotee and the reason as perceived by co-worker A and B. Please note that there are some discrepancies between the official and self-reported reasons for the demotion decision.

\section{INSERT TABEL 2 HERE}

\subsection{Procedures}

We used a flexible interview agenda for both phases with a semi-structured format. This allowed for an 'emic' understanding of how participants interpreted their experiences and their subsequent thoughts. All interviews were conducted using skype and were recorded with participants' permission. The interview agenda comprised a core set of questions focusing on (1) a description of the demotion situation; (2) feelings and experiences associated with the demotion; (3) perceptions as to why they were demoted. Each interview lasted between 70 and 100 minutes.

While demotion may be experienced as an individual event it occurs in a social context, so we were interested in the social context and relationships specifically in participants' understanding of the demotion experience. Pursuing this line of enquiry seems especially valuable given that someone who has been demoted will continue to work in an organization and will continue to interact with others with whom, organizationally, they may have had a different relationship before the demotion.

\subsection{Data analysis}


We used thematic analysis to code the data (King, 2004) with reference to the overarching concept of social capital. As we were only interested in the social capital elements of demotions, we did not code any other themes. Our analysis indicated the importance of social capital as a major factor, though not the only one, in demotion decisions. Table 3 provides the frequencies of types of capital that were mentioned by the participants.

\section{INSERT TABLE 3 HERE}

We developed some of the themes a priori based on our reading of the literature, for example 'socializing in the workplace' or 'playing the game' (McArdle, Waters, Briscoe \& Hall, 2007; Seibert et al., 2001). Others were added as the analysis evolved, such as 'building relationships' and 'being visible'. The data was coded using the Gioia Method (Gioia, Corley \& Hamilton, 2013). In the first step, we created the 'first order coding', providing a descriptive assessment of the data. At this stage we were interested in adhering "faithfully to informant terms" (Gioia et al., 2013: 20).

\section{INSERT FIGURE 1 HERE}

We then created 'higher order themes' progressing towards a more conceptual understanding of the data. This involved further iteration between literature and themes. For example, as shown in Figure 1, we conceptualised participants' responses in terms of their perception of the characteristics of the organizational and interpersonal contexts and climate, and in relation to their own career trajectories or those of their co-workers (e.g., importance of relationships with regards to career development and managing visibility). This second order analysis enabled the development of 'aggregate dimensions', indicating how demotion is 
perceived as partly a consequence of a lack of relevant social capital. In addition, we identified personal characteristics that influence the ability to build relationships, socialise and be visible.

\section{Findings}

In this section we present our findings. We start by outlining the perceived personal characteristics that may influence the ability to socialise; to build positive relationships with managers; socialise with other organizational members and; be visible to others. Following this, we highlight demotees' and co-workers' perceptions of the interpersonal dynamics in their organization and then consider themes that relate to their perceptions of the broader interpersonal and social aspects of their workplace (e.g., organizational climate and culture) and how they felt they had impacted on the demotion decision.

It is important to highlight that the demotees had either a proximal or distal relationship with their co-workers who reported on the demotion and that this was expected to affect how the co-workers perceived the demotion decision. When they had a close relationship (were friends), they reported in similar ways on the demotion, echoing each other in terms of what they thought had led to the demotion. However, even when this relationship was more distant, their perspectives did mostly align, which shows that a possible bias based on whether demotees and co-workers were friends is seems to be minimal.

\subsection{Personal characteristics}

Several personal characteristics emerged as important factors that hindered or facilitated the ability of demotees to build positive relationships with important others, socialise with decision-makers in the organization and be visible. Personality traits such as introversion were mentioned as barriers: 
Socializing is extremely important. Getting along with your manager really does help your career. Our relationship is not bad, but it does not go beyond a rather formal relationship. I know that he phones some of my colleagues over the weekend and stuff, but I'm probably too shy and not spontaneous enough to open myself and be more relaxed and informal with him (demotee 13).

What is important in this respect is the extent to which some participants believed that demotion decisions may be predicated on individual's 'innate' personality characteristics rather than problems with individual performance. Co-workers also spoke about this theme:

Is it really about his performance? I doubt it. He's probably too modest and shy to show what he's worth (co-worker 21a).

There was also a wider belief that there was nothing they could have done to prevent themselves from being demoted as they did not possess the 'right personality' to acquire the requisite social capital. Note how the demotee below describes himself as 'too shy' to be able to socialise and build a good relationship with his manager which reduced his visibility.

My shy personality has maybe influenced [the demotion]. You have to be extrovert, social and easy-going with people, while I'm everything but all that. I think that for most careers and going up in the hierarchy, being an introvert is problematic (demotee 1). 
There was also a perception among the non-native Dutch speakers that the ability to develop their social capital in the form of relationships was impacted by linguistic capability:

\begin{abstract}
I'm not a native Dutch speaker and although my Dutch is quite good, I miss some nuances. This hinders our relationship (with the manager) as I don't understand his jokes. It's not a big deal, but our relationship is probably more distant (demotee 3).
\end{abstract}

Here we see further evidence of how demotees may believe that it is their inability to build relationships-in this case due to limited fluency in the host country language-which impacts demotion decisions. Moreover, participants spoke about how their capacity to socialise, be visible or connect with others at work was limited by their social background, socioeconomic status or gender.

Maybe it had to do with my working-class roots. I didn't have all the codes, the norms that the others seem to have. I don't say that that's the reason I got demoted, but it made me different from others. It didn't help me to bond and build good relationships at work, it made me a bit of an outsider. They were all similar. They shared the same social status, enjoy the same activities, sports, hobbies. For me, it's different. I didn't grow up the same way (demotee 2).

I think that being in certain circles, like your socioeconomic status and being surrounded by people who know important people and can get things done is an issue. Because of these circles, people have access before others do and can circumvent things like demotions. I don't have such a security net in terms of family, money and network, making me more vulnerable (demotee 23). 
This finding was corroborated by many of the co-workers:

I think it has been pretty difficult for him. He's struggling to integrate a little as he's just different. I'm not sure whether that has played a role in his demotion but I suspect it does as I don't see any other reason (co-worker 10b).

Several demotees who believed that their lack of visibility had impacted on their being demoted said that they also lacked 'the right personality' to become visible:

Based on my background and upbringing, I have had less confidence. This has been a strong barrier in my career development. I mean, people who never raise their hands and do not speak up do not go far (demotee 11).

Moreover, while these participants identified their having the 'wrong personality' or social background to ensure visibility, many also identified colleagues who they thought had the 'right' personality or social background:

This colleague of mine is good at impression management: she's always hanging out with top management and she's showing her work to them to make sure they remember how valuable she is to the organization. I'm sure that it actually works, that it makes her more visible somehow compared to someone like me as I'm never showing off my accomplishments (demotee 14). 
This finding signals that it is not the demographic characteristic itself that impacts on demotion decisions but rather its perceived impact on their ability to socialise, maintain proximal relationships with other organizational members and create visibility. Conceptually, these characteristics refer to embodied cultural capital (Bourdieu, 1990), acquired through socialization to culture and/or tradition. Moreover, the manner in which symbolic elements (posture, clothing, mannerisms, confidence) are embodied and valued in ways that lead to structured differentiation between people based on such capital. Participants who refer to lacking 'codes' or appropriate scripts for behaviour are indicating that they feel that they lack relevant embodied cultural capital.

\subsection{Employee-management relationships}

A dominant theme among the demotees was their perceptions of the centrality of the employee-employer relationship and specifically the relationship between them and their immediate manager. Work relationships generally refer to patterns of exchanges between two interacting members directed at the accomplishment of some common objectives (Ferris, Liden, Munyon, Summers, Basik \& Buckley, 2009). Work relationships, especially positive interpersonal relationships (Ragins \& Dutton, 2007), play an important role in organizations. Past research has focused on the overall quality of interpersonal interactions: the degree of trust, respect, loyalty, and felt mutuality that characterises good work relationships (Ferris et al., 2009). Most participants emphasised that a 'good' or 'positive' relationship offered protection against demotion, as well as redundancy. On the other hand, 'negative' or 'neutral' relationships were understood to offer little protection and, in some cases, more likely to invite the potential for demotion or job loss - but particularly demotion in contexts where termination of an employees' contract could be contested legally. They also noted that this type of mutually supportive relationship enhanced the possibility of promotion and pay 
raises. This is in line with Feeney and Collins (2015) who showed that relationships help individuals pursue opportunities for growth in the absence of adversity. 'Good' and/or 'positive' were widely used adjectives to describe relationships which might involve occasional socialising outside of work, exchanging information about non-work lives, e.g. family and friends. Taking a social network stance, we highlight the dyadic relationship between employees and their managers. Such an approach classifies individual actors as nodes, while relationships between actors are represented by ties (Ferris et al., 2009) and the main focus is on the beneficial functions they serve (Rousseau \& Ling, 2007).

The idea of being friends and friendship was particularly important in their perceptions of the quality of relationships with respective managers and of why they had been demoted. The centrality of friendship here echoes the literature on friendship in the workplace (Costas, 2012) where, for example, friendship can be a source of protection from the negative dimensions of organizational life (Colbert, Bono \& Purvanova, 2016). This can be related to Bowlby's (1988) attachment theory, that posits that relationships may serve as a safe haven in times of stress as well as a secure base that promotes growth. The findings show that a lack of friendship or the presence of antipathy invites negative outcomes:

She really has her own friends that she protects. It's subtle you know, things are not always transparent. All of a sudden a good friend of hers got this promotion and the position had not been publicly advertised as far as I know. As we have a neutral relationship, nothing bad, but also nothing special. I'm quite sure I was the first one on the list to be proposed a demotion (demotee 4). 
You don't let down your friends, so that's what happened. When it came to the decision who should get demoted, he kept all his friends, not because they are the best workers, but because they are his friends (demotee 13).

These examples indicate how friendships with managers might be cultivated in the workplace as a source of potential 'special treatment' or in some cases as offering a form of 'protection' against demotion. This was evident in many of the interviews, where friendship, as an embodiment of social capital in the workplace operates to include and exclude. This finding was echoed by the co-workers:

It's a shame that the organization is so screwed up. It's completely non-transparent and highly political. I don't trust the organization. It's probably more about friendships then about anything else (co-worker 22a).

The concept of 'exclusion' was prominent among demotees where many spoke about being 'excluded' from friendships with their managers which they felt had had a direct influence on their having been demoted compared to their counterparts who they described as being on 'friendlier terms'.

Demotees' perceived lack of inclusion in friendship networks with management led to their belief that there was a lack of transparency, that their organization was unethical and that they had to conform to a certain way of being to avoid being demoted. Several participants were adamant that it was precisely their lack of friendship with their manager that had resulted in their being demoted, which was again corroborated by their co-workers who shared this perception of an unethical and political climate: 
There are always two sides to a story and I might be biased as I'm also a good friend of [the demotee]. However, it seems that there were no clear reasons why he had to step down apart from not being able to play the organizational politics. I think it says a lot about the values in here, that's it not what you do, your objective performance, but who you know (co-worker 5a).

I'm sure that in a place where people are ethical and have a clear vision of how things should be done, you do not have those random decisions where it's all about who's your friend rather than how valuable a person truly is (demotee 11).

Whereas this finding might appear overly deterministic in the sense that you are either friends with your manager or not, further analysis indicated widespread awareness of the dynamic and composite nature of workplace interactions and relationships where friendships between employees and managers were widely understood as open to change. Thus, when a manager leaves an organization, the old friendship network disappears with the concomitant understanding that those employees who previously benefited from the respective friendship may no longer do so, while others who were not in the previous friendship network now have the opportunity to create new social capital with the new manager:

I have the impression that [the new manager] just didn't like me. He wanted to get his own friends in the team and seemed to want to get rid of me. It clearly had nothing to do with my performance as I've always had positive appraisals throughout my career (demotee 22). 
We see here how friendship between employees and managers, as a form of 'social capital', was perceived as having a direct impact on demotion decisions.

\subsection{Ability to socialise with other organizational members}

Another dominant theme was the ability to socialise and the extent to which employees can connect on an interpersonal level with management. Socialization here does not refer to organizational socialization as defined as "the process by which an individual acquires the social knowledge and skills necessary to assume an organizational role" (Van Maanen \& Schein, 1979: 211), but instead focuses on the relationship building aspect of interactions (Ferris, Treadway, Kolodinsky, Hochwarter, Kacmar, Douglas \& Frink, 2005). Whereas this ability was seen as enabling friendships, it was also seen by both the demotees and coworkers as a general form of behaviour which might impact the likelihood of being demoted. Being able to socialise effectively with the "right" people was also observed by the coworkers:

There are obviously two sides and I don't know who to believe: the organization who offers a beyond-our-control explanation or [demotee's name] who says it's been very subjective and unfair. I don't know, but I tend to believe him as the organization is very much about who-knows-who (co-worker 18a).

Participants spoke about their inability or unwillingness to 'play the game' referring to whether they socialised with other organizational members including managers and other colleagues. Participants identified how it had resulted in their being demoted. We observe widespread recognition of 'soft skills' in the contemporary management literature (Longenecker, Neubert \& Fink, 2007). Exploring the concept of 'ability to socialise' in more 
detail, participants referred mainly to the ability to engage in positive daily interactions with other organizational members. Participants talked about being able to engage in 'organizational politics' including establishing close working relationships with people that they did not know well or did not have a great deal in common with. Co-workers confirmed this line of thinking, although some perceived the ability to engage in political behaviour as part of their job:

It's been a political decision obviously, but that's also part of your job. Networking and being surrounded by people that can get things done are skills that you need, no matter what job you have nowadays. If you don't have those skills you won't go far (co-worker 17b).

She wasn't very visible, I don't say you should get punished for that, but it's a big part of the game (co-worker $9 b$ ).

The participant below talked about how his inability to socialise and build a relationship with his manager rather than his ability to do his job which had resulted in demotion.

Some people just play the game. They know how to do it, to chat and socialise with others. Others don't really know, they just get their work done. It's sad that good hard-working people do not get the recognition they deserve (demotee 16).

The same observation was made by several co-workers, which they said opened their eyes and made them realise the importance of effective interpersonal behaviour. 
I think he got demoted because he wasn't so good at playing the game, networking, hanging out with the right guys, these things. I'm not saying I'm now socializing with the right people to avoid a demotion, but I'm more aware of how important it is (coworker 18a).

Ifeel it's been a very political decision. He has a very good profile and seemed the ideal candidate, ready for a next step in his career. Against all odds he got demoted. The reason behind it can only be a hidden, non-objective one (co-worker 17a).

This finding points to the value of conformity in organizational life, where the "conforming self' (Collinson, 2003) offers protection against being demoted. Individuals who are able and willing to conform to these requirements are less likely to be demoted. While sociability relates to being able to establish friendships with managers, it is essentially about making otherwise weak relationships with a broader range of stakeholders stronger.

\subsection{Creating Visibility: Being Visible}

Another dominant theme was 'visibility' where decisions about who gets demoted were perceived as relating to which employees were most visible in the workplace.

It's important to be visible in here. If people cannot remember who you are and what you do, they'll think you are useless and will get rid of you. But being visible is not easy for everyone, it has to do with your personality, with being social and eloquent (demotee 17). 
I probably didn't show off enough. I'm the one working quietly, without getting noticed. Being passed over for promotions because I don't put myself forward and people don't think about me because I'm not being noticed, because I'm not visible (demotee 1).

This theme was also echoed by co-workers:

The poor guy, I'm really sad for him. It's been about being visible and playing this horrible game, he just couldn't bear it anymore. It says so much about what we value here! Being a competent and NICE person is no longer enough (co-worker $1 b$ ).

Two points are worth noting here. First, performance is not in itself enough to be sure of not being demoted under conditions where demotion is a managerial option. Second, 'getting noticed' and being visible is an important part of managing performativity at work. This finding may have broader implications for organizational culture.

Decisions there were not being based on some kind of objective measure of something. It was all about being visible and getting along with the main decisionmakers. I think it's pretty sad, because it's not an incentive for working hard, but it's the way things are around there (demotee 10).

The theme of being 'visible' to other organizational members and particularly to decisionmakers has been identified as a key concern to avoid career derailment and demotion, such as is the case for flexible workers (Richardson \& Kelliher, 2015). In addition, being visible was often related to engaging in political behavior including impression management techniques 
such as showing one's accomplishments to individuals with power, sometimes taking credit for work that had been conducted in a team, appearing busy and staying at work for long hours.

There is this political aspect where giving the impression that one is important, works hard and gets a lot done is paramount. What someone's real value is for the organization is often neglected. The appearance is enough (co-worker 22a).

Demotees reflected on this issue and wondered if they could have prevented a demotion by playing politics, being visible and showing their value to managers.

It makes you think not only about what makes you go up, but also what protects you from going down. I'd love to think it's a fair process, but deep inside I guess it's about who knows who, who's best in politics, who's good at managing the impressions one leaves on others (demotee 4).

Finally, it is important to stress the inter-related nature of being visible, building positive relationships and socializing as well as the personal characteristics that seem to influence the demotion decision. Rather than treating them as separate constructs, both the demotees and the co-workers highlight how one's personal characteristics, such as personality, linguistic ability or communication skills and, socioeconomic background, which determines access to 'codes', 'scripts' and certain 'norms', influence the ease with which an individual engages in impression management and increases their visibility, ability to socialise with others and/or build good relationships with their superiors. 


\section{Discussion}

Located within a social constructivist paradigm, we provided demotees the opportunity to reflect and report on their personal experience of demotion and how this decision came about. Using a social capital framework, this study seeks to theorise involuntary demotees' and their co-workers' perceptions of demotion decisions. Participants reported that demotion is impacted by a number of key influences: first, their personal characteristics that in turn affect the quality of relationships with managers. Second, their capacity and motivation to socialise with other organizational members and third, the extent to which they are visible to other organizational members, particularly managers. These findings are depicted in Figure 2.

\section{INSERT FIGURE 2 HERE}

Drawing on social capital theory, this paper proposes that there is widespread awareness of the interpersonal and social nature of demotion decisions, where demotees' inability or lack of motivation to socialise with other organizational members, to develop career and work enhancing relationships with managers, and their organizational visibility played important roles in their being demoted. These findings signal the centrality of social capital in demotion decisions and adds to our understanding of how a lack of social capital can have detrimental effects on an individual's workplace and career success and experiences.

First, even while participants were aware of the need to develop positive relationships/friendships with other organizational members, they had not taken steps to build or maintain those relationships. As shown in Figure 2, a connection was identified between the quality of relationships with managers and demotion decisions. Likewise, demotees had not taken steps to enhance their visibility. They had been aware of these connections prior to being demoted but had not acted upon that knowledge. We might wonder why they had not 
taken preventative measures. One explanation is that whereas many demotees connected their inability or lack of motivation to socialise or establish positive working relationships with 'personal characteristics' they seemed to see overcoming this as beyond their individual control. This draws attention to the influence of factors such as class, personality, linguistic ability, race and socioeconomic status on the relationship between employees and their managers and how it restricts their ability to develop appropriate and relevant social capital.

Second, while Figure 2 provides a framework as to demotees' understanding of why they had been demoted, it also provides for an understanding of why they believe that other colleagues had not been demoted. There was a widespread belief that non-demoted individuals had developed positive working relationships, and in some cases friendships, with managers. Likewise, participants reported that those colleagues had greater ability and willingness to socialise and/or to maintain high levels of visibility. In this regard the model explains both why an individual might be demoted and,why they had not. From a social capital theory perspective there is widespread evidence in our sample of the value of building social capital in order to protect oneself against demotion given that both demotees and their non-demoted colleagues consider it to be so.

Third, it should be noted that none of the participants in this study connected being demoted with work performance. Indeed, there were widespread accounts of how their performance had been in some cases above organizational expectations. Of course it may be that their reluctance to acknowledge problems with work performance reflects a form of defensive behaviour where they are seeking to present a more positive self-image. However, they acknowledge other problems which they also believe were a result of their own behaviour and within their control, such as not socialising with other organizational members, and not maintaining their visibility. Thus, it is not that they are denying responsibility but rather not connecting the decision with their performance. Participants linked their demotion 
to the social and interpersonal aspects of their workplace and their own behavioural and personality characteristics and 'deficiencies' rather than objective performance measures. This finding aligns with research that highlights the darker side of temporary careers which highlight the importance of impression management and conformity in organizational and career success and survival (Edelman et al., 2004). What we observe here is that social capital is understood as a key determinant of who gets demoted rather than the more 'objective' measures of individual work performance.

The article has also shown how some participants explained inability or lack of motivation to develop social capital and/or enhance their visibility by referring to their lack of embodied cultural capital (Bourdieu, 1985). In a broad sense this relates to a 'bundle' of accumulated knowledge and other assets that confer privileges, status and opportunity on some people but not others. This cultural capital is manifested in certain 'codes', 'norms' and 'scripts' that are associated with these privileges and which enable greater interpersonal confidence among individuals who embody this cultural capital. Demotees felt that they lacked the cultural capital that comes with socioeconomic status and background and its associated codes, scripts, norms and beliefs which would have protected them from demotion. They felt that the failure to build relationships at work, be visible and engage in impression management were related, in academic terms, to a lack of appropriate habitus or embodied dispositions i.e. they lacked the "transposable dispositions" (Bourdieu, 1990: 53) that would allow them to develop the requisite forms of social capital.

\subsection{Theoretical Contributions}

This paper makes three theoretical contributions.

First, locating our study within social constructivism, we add to a growing body of literature on the dark side of social capital (Edelman et al., 2004; Locke, 1999). We do so by 
showing how a lack of social capital can negatively contribute to the development of an individual's career

Second, in accordance with a growing number of scholars who view the value of social capital as affected by more than the structure of an individual's ties (Nahapiet \& Ghoshal, 1998; Adler \& Kwon, 2002; Wang \& Seifert, 2017), we add to our understanding of relational embeddedness, which has received much less attention from researchers than structural embeddedness. In the context of demotion decisions, we show that it is not the configuration of one's network, but rather the quality of those relationships that influences the likelihood that someone will be involuntarily demoted. While previous research has shown that individuals with high leader-manager exchange (LMX)-relationships with their immediate leaders gained influence when being sponsored by their leaders (Sparrowe \& Liden, 2005), we show that the lack of a good relationship has a negative impact on career development.

Third, we answer a call for more research on the dyad-specific qualities of social capital (Uzzi, 1997) by showing that being different from the decision-makers in for example socioeconomic status, class or ethnicity, had a negative impact on the quality of their relationships, and the relational embeddedness aspect of their social capital.

Finally, by combining the lived career experiences of demotees and co-workers, we identify the value of social constructivism in conceptualizing how demotion decisions are made and specifically articulate who has a greater chance of being demoted. Notwithstanding performance criteria, we signal the role of relationships as a precursor to the identification of potential demotees.

Overall our contributions can be linked more broadly to the substantial research that has been undertaken on the importance of social capital and networks throughout human resources management, careers and, business activity more generally (Bolander, 2015; 
Boxman \& Henk, 2017; Cope, Jack, \& Rose, 2007; Hollenbeck \& Jamieson, 2015;

McGowan, 2015; Moran, P, 2005; Nowinsky \& Rialp, 2016; Richardson \& McKenna, 2014;

Seibert, Kraimer, \& Liden, 2001; Spurk et al., 2015). This research shows that social capital, networks and relationships have positive effects on careers, promotion, recruitment, business expansion, small business development and many other aspects of personal, organizational and business activity. If this is the case, then, concomitantly it cannot be surprising that a lack of such capital, networks and relationships will not only have a neutral effect, but under certain circumstances have a negative impact. Whereas human capital is often viewed as critical to career success, it is social capital or lack thereof which might leave individuals more exposed to negative decisions that are imposed upon employees.

\subsection{Practical Implications}

While human capital theories would expect performance to be the primary factor impacting demotion decisions (Werner \& Bolino, 1997), social capital theory identifies interpersonal behaviour and relationships as key influences. This finding echoes arguments that performance management is prone to biases such as groupthink and the recency effect (Ariely, Bracha \& Meier, 2009), but it also highlights the significance of the relational factors of organizational life. Moreover, other interpersonal factors have been found to influence organizational decision-making processes such as relationships between managers and employees (Wayne, Liden, Kraimer \& Graf, 1999); ability to socialise and engage in political behaviour (McArdle et al., 2007; Ferris et al., 2005; Seibert et al., 2001) and to create visibility (Richardson \& Kelliher, 2015). This paper has echoed previous research but has also added to our understanding of demotion. This is therefore something which management needs to take into consideration in order to ensure perceptions of procedural equity. The issue of equity is particularly important because transparency and perceptions of justice have been 
found to be linked to a range of positive outcomes for organizations (Lam, Schaubroeck \& Aryee, 2002), whereas opaque decisions and perceptions of favouritism have been related to negative outcomes (Pettigrew, 2014). This implies that when demotion decisions are based, or perceived to be based, on subjective criteria it may have negative performance outcomes. Managers may want to avoid this situation by outlining clear objectives and being transparent about decisions regarding demotion. However, such obviously rational behaviour is not often possible in the context of the fluid and dynamic interpersonal aspects of organizations.

\subsection{Limitations and Suggestions for Future Research}

Although this study adds to the emerging literature on demotion, future researchers may wish to bear in mind the following issues:

First, the time between the demotion taking place and this study varied from a few weeks to a few years. It is possible that with time individuals' feelings and attitudes about the demotion decision may change thus suggesting the need for longitudinal studies.

Second, participants' perceptions need to be juxtaposed with those of managers. For a number of reasons we might expect managers to respond differently. Third, whereas this study was carried out in The Netherlands it may be that demotion decisions are understood differently in other cultural contexts. A comparative study may be useful in highlighting the impact of institutional factors and logics on perceptions of demotion decisions. Likewise, further studies may explore the extent to which men and women or different age groups perceive those decisions.

Fourth, a social desirability bias needs to be acknowledged as demotion is a sensitive topic. We adopted several strategies to minimize social desirability bias, such as ensuring anonymity and voluntary participation as well as stressing that there were no right or wrong answers. 


\section{Conclusion}

Whereas it might be hoped that only specific job-related performance would be considered in managerial decisions about demotion, we must also acknowledge that the capacity to develop and maintain social capital, in the form of good working relationships, socializing and developing and maintaining visibility, are all important organizational and career skills (Bozionelos, 2015). Those who believe that social capital is not an aspect of role performance and that it need not be developed, will continue to be disadvantaged under circumstances where such capital plays a role in managerial decisions about demotion.

\section{References}

Adler, P. S. \& Kwon, S. W. (2002). Social capital: Prospects for a new concept. Academy of Management Review, 27, 17-40. https://doi.org/10.2307/4134367.

Ariely, D., A. Bracha \& Meier, S. (2009). Doing good or doing well? Image motivation and monetary incentives in behaving prosocially. American Economic Review, 99, 544555. https://doi.org/10.1257/aer.99.1.544.

Arthur, M. B., Khapova, S. N. \& Richardson, J. (2017). An Intelligent Career: Taking Ownership of Your Work and Your Life. New York: Oxford University Press.

Bolander, W., Satornino, C. B., Hughes, D. E., \& Ferris, G. R. (2015). Social networks within sales organizations: Their development and importance for salesperson performance. Journal of Marketing, 79, 1-16. https://doi.org/10.1509/jm.14.0444.

Bourdieu, P. (1985). The social space and the genesis of groups. Information (International Social Science Council), 24, 195-220. https://doi.org/10.1177/053901885024002001.

Bourdieu, P. (1990). 'Structures, habitus, practices'. In P. Bourdieu, The Logic of Practice, pp. 52-65. Cambridge: Polity Press.

Bourdieu, P. (2011). 'The forms of capital (1986). In I. Szeman and T. Kaposy (Eds), Cultural Theory: An Anthology, 1, pp. 81-93. Chichester, UK: John Wiley and Sons.

Bowlby, J. (1988). A Secure Base. New York, NY: Basic Books.

Boxman, E., \& Flap, H. (2017). Getting started: the influence of social capital on the start of the occupational career. In Social capital, pp. 159-181. New York: Routledge.

Bozionelos, N. (2015). 'Social capital and careers: Indisputable evidence and note for caution'. In A. De Vos \& B. I. J. M. Van der Heijden (eds.), Handbook of Research on Sustainable Careers, pp. 67-82. Cheltenham, UK: Edward Elgar.

Carson, P. P. \& Carson, K. D. (2007). Demystifying demotion: A look at the psychological and economic consequences on the demotee. Business Horizons, 50, 455-466. https://doi.org/10.1016/j.bushor.2007.05.003.

Colbert, A. E., Bono, J. E., \& Purvanova, R. K. (2016). Flourishing via workplace relationships: Moving beyond instrumental support. Academy of Management Journal, 59, 1199-1223. http://dx.doi.org/10.5465/amj.2014.0506. 
Collinson, D. C. (2003). Identities and insecurities: Selves at work. Organization, 10, 52747. https://doi.org/10.1177/13505084030103010.

Cope, J., Jack, S., \& Rose, M. B. (2007). Social capital and entrepreneurship: An introduction. International Small Business Journal, 25, 213-219. doi: $10.1177 / 0266242607076523$.

Costas, J. (2012). "We are all friends here" - Reinforcing paradoxes of normative control in a culture of friendship. Journal of Management Inquiry, 21, 377-395. https://doi.org/10.1177/1056492612439104.

Dohmen, T. J., B. Kriechel \& Pfann, G. A. (2004). Monkey bars and ladders: The importance of lateral and vertical job mobility in internal labor market careers. Journal of Population Economics, 17, 193-228. https://doi.org/10.1007/s00148-004-0191-4.

Domínguez, S. and Hollstein, B. (Eds.). (2014). Mixed Methods Social Networks Research: Design and Applications. Cambridge: Cambridge University Press.

Edelman, L. F., Bresnen, M., Newell, S., Scarbrough, H. \& Swan, J. (2004). The benefits and pitfalls of social capital: Empirical evidence from two organizations in the United Kingdom. British Journal of Management, 15, 59-69. https://doi.org/10.1111/j.14678551.2004.00406.x.

Elfenbein, D. W., \& Zenger, T. R. (2014). What is a relationship worth? Repeated exchange and the development and deployment of relational capital. Organization Science, 25, 222-244. https://doi.org/10.1287/orsc.2013.0824

Feeney, B. C. \& Collins, N. L. (2015). A new look at social support: A theoretical perspective on thriving through relationships. Personality and Social Psychology Review, 19, 113-147. https://doi.org/10.1177/1088868314544222.

Ferraris, A., Santoro, G., \& Scuotto, V. (2018). Dual relational embeddedness and knowledge transfer in European multinational corporations and subsidiaries. Journal of Knowledge Management. https://doi.org/10.1108/JKM-09-2017-0407

Ferris, G. R., Liden, R. C., Munyon, T. P., Summers, J. K., Basik, K. J. \& Buckley, M. R. (2009). Relationships at work: Toward a multidimensional conceptualization of dyadic work relationships. Journal of Management, 35, 1379-1403. https://doi.org/10.1177/0149206309344741.

Ferris, G. R., Treadway, D. C., Kolodinsky, R. W., Hochwarter, W. A., Kacmar, C. J., Douglas, C. \& Frink, D. D. (2005). Development and validation of the political skill inventory. Journal of Management, 31, 126-152. https://doi.org/10.1177/0149206304271386.

Gioia, D. A., K. G. Corley \& A. L. Hamilton (2013). Seeking qualitative rigor in inductive research: Notes on the Gioia methodology. Organizational Research Methods, 16, 1531. https://doi.org/10.1177/1094428112452151.

Hennekam, S. (2016). Identity transition during pregnancy: The importance of role models. Human Relations, 69, 1765-1790. https://doi.org/10.1177/0018726716631402.

Hennekam, S., Ananthram, S. \& McKenna, S. (in press). Co-workers' perceptions of and reactions to employee's involuntary demotion. Employee Relations.

HR Kiosk the Netherlands (2018). Demotie. Available at: https://www.hrkiosk.nl/hoofdstuk/belonen/demotie (accessed 9 July, 2018).

Hollenbeck, J. R., \& Jamieson, B. B. (2015). Human capital, social capital, and social network analysis: Implications for strategic human resource management. Academy of Management Perspectives, 29, 370-385. https://doi.org/10.5465/amp.2014.0140

Inkpen, A. C., \& Tsang, E. W. (2005). Social capital, networks, and knowledge transfer. Academy of Management Review, 30, 146-165. https://doi.org/10.5465/amr.2005.15281445 
Kim, S. (2013). Networking enablers, constraints and dynamics: a qualitative analysis. Career Development International, 18, 120-138. https://doi.org/10.1108/CDI-042012-0051.

King, N. (2004). Using templates in the thematic analysis of text. Essential guide to qualitative methods in organizational research, 2, 256-70.

Kooij, D. T., Guest, D. E., Clinton, M., Knight, T., Jansen, P. G. \& Dikkers, J. S. (2013). How the impact of HR practices on employee well-being and performance changes with age. Human Resource Management Journal, 23, 18-35. https://doi.org/10.1111/1748-8583.12000.

Krause, R. \& M. Semadeni (2013). Apprentice, departure, and demotion: An examination of the three types of CEO-Board separation. Academy of Management Journal, 56, 805826. https://doi.org/10.5465/amj.2011.0121.

Kwon, S. W. \& Adler, P. S. (2014). Social capital: Maturation of a field of research. Academy of Management Review, 39, 412-422. https://doi.org/10.5465/amr.2014.0210.

Lam, S. S., Schaubroeck, J. and Aryee, S. (2002). Relationship between organizational justice and employee work outcomes: a crossnational study. Journal of Organizational Behavior, 23, 1-18. http://www.jstor.org/stable/4093682.

Levin, D. Z., Walter, J., Appleyard, M. M., \& Cross, R. (2016). Relational enhancement: How the relational dimension of social capital unlocks the value of network-bridging ties. Group \& Organization Management, 41, 415-457. https://doi.org/10.1177/1059601115574429

Locke, E. A. (1999). Some reservations about social capital. Academy of Management Review, 24, 8-9. https://doi.org/10.5465/amr.1999.15873796.

Longenecker, C. O., M. J. Neubert \& Fink, F. S. (2007). Causes and consequences of managerial failure in rapidly changing organizations. Business Horizons, 50, 145-155. https://doi.org/10.1016/j.bushor.2006.11.002.

MacLeod, W. B. \& Malcomson, J. M. (1988). Reputation and Hierarchy in Dynamic Models of Employment. Journal of Political Economy, 96, 832-854. http://www.jstor.org/stable/1830476.

Marsden, P. V. (2017). Interpersonal ties, social capital, and employer staffing practices. In Social capital, pp. 105-125. New York: Routledge.

Maurer, I., Bartsch, V. \& Ebers, M. (2011). The value of intra-organizational social capital: how it fosters knowledge transfer, innovation performance, and growth. Organization Studies, 32, 157-185. https://doi.org/10.1177/0170840610394301.

McArdle, S., L. Waters, J. P. Briscoe \& D. T. Hall (2007). Employability during unemployment: Adaptability, career identity, and human and social capital. Journal of Vocational Behavior, 71, 247-264. https://doi.org/10.1016/j.jvb.2007.06.003.

McGowan, P., Cooper, S., Durkin, M., \& O'Kane, C. (2015). The influence of social and human capital in developing young women as entrepreneurial business leaders. Journal of Small Business Management, 53, 645-661. https://doi.org/10.1111/jsbm.12176

Meuleman, M., Jääskeläinen, M., Maula, M. V., \& Wright, M. (2017). Venturing into the unknown with strangers: Substitutes of relational embeddedness in cross-border partner selection in venture capital syndicates. Journal of Business Venturing, 32, 131-144. https://doi.org/10.1016/j.jbusvent.2017.01.001

Moran, P. (2005). Structural vs. relational embeddedness: Social capital and managerial performance. Strategic Management Journal, 26, 1129-1151. https://doi.org/10.1002/smj.486

Nahapiet, J. \& Ghoshal, S. (1998). Social capital, intellectual capital and the 
organizational advantage. Academy of Management Review, 23, 242-266. https://doi.org/10.2307/259373.

Nowiński, W., \& Rialp, A. (2016). The impact of social networks on perceptions of international opportunities. Journal of Small Business Management, 54, 445-461. https://doi.org/10.1111/jsbm.12149

O'Leary, Z. (2004). The Essential Guide to Doing Research. London: Sage.

Pettigrew, A. M. (2014). The Politics of Organizational Decision-making. Abingdon: Routledge.

Pillai, K. G., Hodgkinson, G. P., Kalyanaram, G. \& Nair, S. R. (2017). The negative effects of social capital in organizations: A review and extension. International Journal of Management Reviews, 19, 97-124. https://doi.org/10.1111/ijmr.12085.

Ragins, B. R. \& Dutton, J. E. (2007). 'Positive relationships at work: An introduction and invitation'. In J. E. Dutton \& B. R. Ragins (Eds.), Exploring Positive Relationships at Work: Building a Theoretical and Research Foundation: 1-25. Mahwah: Lawrence Erlbaum.

Richardson, J, Jogulu, U. \& Rentschler, R. (2017) Passion or people? Social capital and career sustainability in arts management. Personnel Review, 46, 1835-1851. https://doi.org/10.1108/PR-02-2016-0023.

Richardson, J. \& Kelliher, C. (2015). 'Managing visibility for career sustainability: a study of remote workers'. In A.De Vos and B. Van der Heijden, Handbook of Research on Sustainable Careers, pp. 116-130. Cheltenham: Edward Elgar Publishing.

Richardson, J., \& McKenna, S. (2014). Towards an understanding of social networks among organizational self-initiated expatriates: a qualitative case study of a professional services firm. The International Journal of Human Resource Management, 25, $2627-$ 2643. https://doi.org/10.1080/09585192.2014.884614

Rousseau, D.M., \& Ling, K. 2007. 'Commentary: Following the resources in positive organizational relationship'. In J. E. Dutton \& B. R. Ragins, Exploring Positive Relationships at Work: Building a Theoretical and Research Foundation, pp. 373384. Mahwah: Lawrence Erlbaum.

Seibert, S. E., Kraimer, M. L. \& Liden, R. C. (2001). A social capital theory of career success. Academy of Management Journal, 44, 219-237. https://doi.org/ $10.2307 / 3069452$.

Sparrowe, R. T., \& Liden, R. C. (2005). Two routes to influence: Integrating leader-member exchange and network perspectives. Administrative Science Quarterly, 50, 505-535. https://doi.org/10.2189/asqu.50.4.505.

Spurk, D., Kauffeld, S., Barthauer, L., \& Heinemann, N. S. (2015). Fostering networking behavior, career planning and optimism, and subjective career success: An intervention study. Journal of Vocational Behavior, 87, 134-144. https://doi.org/10.1016/j.jvb.2014.12.007.

Staw, B. M. (1981). The escalation of commitment to a course of action. Academy of Management Review, 6, 577-587. https://doi.org/ 10.2307/257636.

Steinmo, M., \& Rasmussen, E. (2018). The interplay of cognitive and relational social capital dimensions in university-industry collaboration: Overcoming the experience barrier. Research Policy. https://doi.org/10.1016/j.respol.2018.07.004

Uzzi B. (1997). Social structure and competition in interfirm networks: the paradox of embeddedness. Administrative Science Quarterly, 42, 35-67. https://doi.org/ 10.2307/2393808.

van Dalen, H. \& K. Henkens (2014). Demotie: panacee in een vergrijzende arbeidsmarkt? http://www.nidi.nl/shared/content/demos/2014/demos-30-04-vandalen.pdf 
van Dalen, H. P., \& K. Henkens (2016). Why demotion of older workers is a no-go area for managers. The International Journal of Human Resource Management. https://doi.org/10.1080/09585192.2016.1239214

Van Maanen, J., \& Schein, E. H. (1979). 'Toward a theory of organizational socialization'. In B. M. Staw, Research in Organizational Behavior, pp. 209-264. Greenwich: JAI Press.

Verheyen, T., Deschacht, N. \& Guerry, M. A. (2016). The occurrence of demotions regarding job level, salary and job authority. Personnel Review, 45, 1217-1239. https://doi.org/10.1108/PR-06-2014-0139.

Verheyen, T. \& Vermeir, B. (2011). Remotie, een stap terug is een stap vooruit. Mechelen: Kluwer.

Wang, Z., McNally, R. \& Lenihan, H. (2018). The role of social capital and culture on social decision-making constraints: A multilevel investigation. European Management Journal. https://doi.org/10.1016/j.emj.2018.04.004.

Wang, W. \& Seifert, R. (2017). Employee referrals: A study of 'close ties' and career benefits in China. European Management Journal, 35, 514-522. https://doi.org/10.1016/j.emj.2016.09.004

Wayne, S. J., Liden, R. C., Kraimer, M. L. \& Graf, I. K. (1999). The role of human capital, motivation and supervisor sponsorship in predicting career success. Journal of Organizational Behavior, 20, 577-595. https://doi.org/10.1002/(SICI)10991379(199909)20:5<577::AID-JOB958>3.0.CO;2-0.

Werner, J. M. \& Bolino, M. C. (1997). Explaining U.S. courts of appeals decisions involving performance appraisal: Accuracy, fairness, and validation. Personnel Psychology, 50, 1-24. https://doi.org/10.1111/j.1744-6570.1997.tb00898.x.

\section{Table 1: Demographic Characteristics of Demotees and Co-workers}

\begin{tabular}{|c|c|c|c|c|}
\hline Int & Gender Age & Sector & Reduction in.. & Relationship with demotee* \\
\hline 1 & Male 41 & Healthcare & Rank & \\
\hline $1 \mathrm{a}$ & Female 33 & Healthcare & & Close co-worker and friend \\
\hline $1 b$ & Male 46 & Healthcare & & Close co-worker and friend \\
\hline 2 & Male & Sales & Rank and pay & \\
\hline $2 \mathrm{a}$ & Male & Sales & & Project team member \\
\hline $2 b$ & Male & Sales & & Project team member \\
\hline 3 & Male & Hospitality & Span of control/pay & \\
\hline $3 a$ & Male & Hospitality & & Direct supervisor/co-worker \\
\hline $3 b$ & Female 56 & Hospitality & & Close co-worker (no friend) \\
\hline 4 & Female 45 & Healthcare & Span of control & \\
\hline $4 a$ & Male 63 & Healthcare & & Distant co-worker \\
\hline $4 \mathrm{~b}$ & Male & Healthcare & & Close co-worker \\
\hline 5 & Male 58 & Financ. serv. & Job title & \\
\hline $5 a$ & Female 45 & Financ. serv. & & Close co-worker and friend \\
\hline $5 b$ & Male 54 & Financ. serv. & & Close co-worker \\
\hline 6 & Male 64 & Education & Responsibilities & \\
\hline $6 a$ & Female 51 & Education & & Direct supervisor \\
\hline $6 b$ & Female 28 & Education & & Distant co-worker/friend \\
\hline 7 & Female 33 & Healthcare & Responsibilities & \\
\hline
\end{tabular}




\begin{tabular}{|c|c|c|c|c|}
\hline $7 \mathrm{a}$ & Male & Healthcare & & Distant co-worker \\
\hline $7 \mathrm{~b}$ & Male & Healthcare & & Close co-worker \\
\hline 8 & Male & Oil & \multicolumn{2}{|l|}{ Benefits } \\
\hline $8 \mathrm{a}$ & Male 42 & Oil & & Close co-worker and friend \\
\hline $8 \mathrm{~b}$ & Female 49 & Oil & & Close co-worker \\
\hline 9 & Female 63 & Healthcare & \multicolumn{2}{|c|}{ Responsibilities/span of control } \\
\hline $9 \mathrm{a}$ & Female 50 & Healthcare & & Close co-worker and friend \\
\hline $9 b$ & Female 48 & Healthcare & & Close co-worker and friend \\
\hline 10 & Male 55 & Education & \multicolumn{2}{|l|}{ Responsibilities } \\
\hline $10 \mathrm{a}$ & Female 63 & Education & & Manager \\
\hline $10 b$ & Female 40 & Education & & Close co-worker and friend \\
\hline 11 & Male 51 & Consulting & \multicolumn{2}{|l|}{ Responsibilities } \\
\hline $11 \mathrm{a}$ & Male 31 & Consulting & & Project team member/friend \\
\hline $11 b$ & Female 38 & Consulting & & Project team member/friend \\
\hline 12 & Male 56 & Healthcare & \multicolumn{2}{|r|}{ - Jер } \\
\hline $12 \mathrm{a}$ & Male 60 & Healthcare & & Distant co-worker \\
\hline $12 b$ & Female 66 & Healthcare & & Close co-worker \\
\hline 13 & Male 55 & Hospitality & \multicolumn{2}{|l|}{ Rank } \\
\hline $13 \mathrm{a}$ & Male & Hospitality & & Close co-worker \\
\hline $13 b$ & Male & Hospitality & & Manager \\
\hline 14 & Female 51 & Healthcare & \multicolumn{2}{|l|}{ Rank } \\
\hline $14 \mathrm{a}$ & Female 44 & Healthcare & & Distant co-worker \\
\hline $14 b$ & Female 51 & Healthcare & & Distant co-worker \\
\hline 15 & Female 40 & Education & \multicolumn{2}{|c|}{ Responsibilities/autonomy } \\
\hline $15 \mathrm{a}$ & Female 68 & Education & & Manager and friend \\
\hline $15 b$ & Male 63 & Education & & Close co-worker \\
\hline 16 & Male 59 & Healthcare & \multicolumn{2}{|l|}{ Responsibilities } \\
\hline $16 \mathrm{a}$ & Female 59 & Healthcare & & Close co-worker and friend \\
\hline $16 b$ & Female 59 & Healthcare & & Distant co-worker/friend \\
\hline 17 & Male 44 & Financial & \multicolumn{2}{|l|}{ Benefits } \\
\hline $17 \mathrm{a}$ & Male 28 & Financial & & Close co-worker and friend \\
\hline $17 b$ & Female 37 & Financial & & Close co-worker \\
\hline 18 & Female 58 & Administrat. & \multicolumn{2}{|c|}{ Responsibilities/span of control } \\
\hline $18 \mathrm{a}$ & Male 55 & Administrat. & & Manager \\
\hline $18 b$ & Male & Administrat & & Close co-worker \\
\hline 19 & Male & Hospitality & \multicolumn{2}{|l|}{ Span of control } \\
\hline $19 \mathrm{a}$ & Male & Hospitality & & Close co-worker and friend \\
\hline $19 b$ & Male 33 & Hospitality & & Close co-worker and friend \\
\hline 20 & Female 59 & Administrat & \multicolumn{2}{|l|}{ Responsibilities } \\
\hline $20 \mathrm{a}$ & Female 40 & Administrat & & Distant co-worker \\
\hline $20 b$ & Male 41 & Administrat & & Distant co-worker \\
\hline 21 & Male & Consulting & \multicolumn{2}{|l|}{ Benefits } \\
\hline $21 \mathrm{a}$ & Male & Consulting & & Project team member \\
\hline $21 b$ & Male & Consulting & & Close co-worker \\
\hline 22 & Male 42 & Healthcare & \multicolumn{2}{|l|}{ Responsibilities } \\
\hline $22 \mathrm{a}$ & Female 45 & Healthcare & & Close co-worker and friend \\
\hline $22 b$ & Female 46 & Healthcare & & Personal assistant/friend \\
\hline 23 & Male 37 & Healthcare & \multicolumn{2}{|l|}{ Rank } \\
\hline $23 a$ & Male 39 & Healthcare & & Close co-worker and friend \\
\hline $23 b$ & Female 47 & Healthcare & & Close co-worker \\
\hline
\end{tabular}


*a distant co-worker works in the same organization, but for example not in the same department, so no close daily contact. A close co-worker interacts daily/weekly with the coworker.

Table 2: Self-reported reasons for the demotion

\begin{tabular}{|c|c|c|c|c|}
\hline Int & Official reason & Reason demotee & Reason co-worker A & Reason co-worker B \\
\hline 1 & $\begin{array}{l}\text { Considered less } \\
\text { suitable than } \\
\text { someone else }\end{array}$ & $\begin{array}{l}\text { Shyness, lack of } \\
\text { visibility }\end{array}$ & $\begin{array}{l}\text { Shyness and lack of } \\
\text { showing } \\
\text { accomplishments }\end{array}$ & $\begin{array}{l}\text { Lack of visibility and } \\
\text { incapacity to play } \\
\text { politics }\end{array}$ \\
\hline 2 & $\begin{array}{l}\text { Clash with } \\
\text { manager }\end{array}$ & $\begin{array}{l}\text { Outsider due to } \\
\text { different } \\
\text { socioeconomic } \\
\text { status, difficulty } \\
\text { to bond }\end{array}$ & Difficulty to socialize & Lacking social skills \\
\hline 3 & Unclear & $\begin{array}{l}\text { Distant } \\
\text { relationship with } \\
\text { manager }\end{array}$ & Unclear & $\begin{array}{l}\text { Not knowing how to } \\
\text { play politics }\end{array}$ \\
\hline 4 & Restructuring & $\begin{array}{l}\text { Neutral } \\
\text { relationship with } \\
\text { manager, lack of } \\
\text { friendship, } \\
\text { unable to play } \\
\text { politics and } \\
\text { manage } \\
\text { impressions }\end{array}$ & Unable to play politics & $\begin{array}{l}\text { Does not know how to } \\
\text { play the game }\end{array}$ \\
\hline 5 & $\begin{array}{l}\text { Negative } \\
\text { performance } \\
\text { appraisal } \\
\end{array}$ & Unsure. & $\begin{array}{l}\text { Lack of fit with the } \\
\text { organization. }\end{array}$ & Unsure. \\
\hline 6 & $\begin{array}{l}\text { Early } \\
\text { retirement }\end{array}$ & $\begin{array}{l}\text { Age and negative } \\
\text { stereotypes about } \\
\text { older workers }\end{array}$ & Age & $\begin{array}{l}\text { Demotion decision is } \\
\text { unrelated to } \\
\text { performance and } \\
\text { competence. }\end{array}$ \\
\hline 7 & Pregnancy & $\begin{array}{l}\text { Negative } \\
\text { stereotypes about } \\
\text { mothers at work }\end{array}$ & $\begin{array}{l}\text { Assumption that one } \\
\text { is less devoted to } \\
\text { work once one } \\
\text { becomes a parent }\end{array}$ & $\begin{array}{l}\text { Demoted because of } \\
\text { pregnancy }\end{array}$ \\
\hline 8 & Downsizing & Age & $\begin{array}{l}\text { Seniority pay, too } \\
\text { expensive. }\end{array}$ & Downsizing \\
\hline 9 & Age & $\begin{array}{l}\text { Negative } \\
\text { stereotypes about } \\
\text { older workers } \\
\end{array}$ & $\begin{array}{l}\text { Unable to network and } \\
\text { show what she is } \\
\text { worth }\end{array}$ & $\begin{array}{l}\text { Lack of visibility, } \\
\text { incapacity to network }\end{array}$ \\
\hline 10 & $\begin{array}{l}\text { Major } \\
\text { restructuring }\end{array}$ & $\begin{array}{l}\text { Lack of visibility } \\
\text { and incapacity to } \\
\text { build strategic } \\
\text { relationships }\end{array}$ & $\begin{array}{l}\text { Difficulties to } \\
\text { socialize and build } \\
\text { relationships }\end{array}$ & Difficulties to integrate \\
\hline 11 & $\begin{array}{l}\text { Negative } \\
\text { performance } \\
\text { appraisal }\end{array}$ & $\begin{array}{l}\text { Lack of } \\
\text { confidence } \\
\text { leading to lack of }\end{array}$ & $\begin{array}{l}\text { No confidence, lack of } \\
\text { pro-active attitude }\end{array}$ & $\begin{array}{l}\text { Does not show what he } \\
\text { is worth }\end{array}$ \\
\hline
\end{tabular}




\begin{tabular}{|c|c|c|c|c|}
\hline & & visibility & & \\
\hline 12 & $\begin{array}{l}\text { Fewer financial } \\
\text { resources }\end{array}$ & $\begin{array}{l}\text { Demotion } \\
\text { decision not } \\
\text { based on } \\
\text { performance or } \\
\text { competence. } \\
\text { Perception of } \\
\text { unfairness. }\end{array}$ & $\begin{array}{l}\text { Unclear where } \\
\text { demotion decision is } \\
\text { based on }\end{array}$ & $\begin{array}{l}\text { Perception that } \\
\text { demotion is unfair }\end{array}$ \\
\hline 13 & Reorganization & $\begin{array}{l}\text { Not friends with } \\
\text { manager, shy, } \\
\text { difficulty to } \\
\text { socialize }\end{array}$ & $\begin{array}{l}\text { Perception that he is a } \\
\text { bit of an outsider }\end{array}$ & Introvert. \\
\hline 14 & Unclear & $\begin{array}{l}\text { Not showing off } \\
\text { accomplishments. } \\
\text { Not networking } \\
\text { and knowing the } \\
\text { right people. }\end{array}$ & $\begin{array}{l}\text { Unable to play } \\
\text { politics. }\end{array}$ & $\begin{array}{l}\text { Does not know how to } \\
\text { play the game. Lack of } \\
\text { political skills. }\end{array}$ \\
\hline 15 & $\begin{array}{l}\text { Consensus } \\
\text { decision }\end{array}$ & $\begin{array}{l}\text { Agreed upon by } \\
\text { both parties. }\end{array}$ & $\begin{array}{l}\text { Solution that worked } \\
\text { for both parties. }\end{array}$ & $\begin{array}{l}\text { Decision reached in } \\
\text { cooperation. }\end{array}$ \\
\hline 16 & Retirement & $\begin{array}{l}\text { Inability to } \\
\text { socialize and } \\
\text { build strategic } \\
\text { relationships }\end{array}$ & $\begin{array}{l}\text { Possibly his age. } \\
\text { Inability to engage in } \\
\text { politics. }\end{array}$ & $\begin{array}{l}\text { Not hanging out with } \\
\text { the right people. }\end{array}$ \\
\hline 17 & $\begin{array}{l}\text { Downsizing to } \\
\text { stay } \\
\text { competitive }\end{array}$ & $\begin{array}{l}\text { Inability to } \\
\text { socialize and be } \\
\text { visible }\end{array}$ & $\begin{array}{l}\text { Organizational } \\
\text { politics. Demotion } \\
\text { decision unrelated to } \\
\text { performance. }\end{array}$ & $\begin{array}{l}\text { Organizational politics } \\
\text { and networking }\end{array}$ \\
\hline 18 & $\begin{array}{l}\text { Demotion to } \\
\text { avoid lay-off }\end{array}$ & $\begin{array}{l}\text { Not visible } \\
\text { enough. }\end{array}$ & $\begin{array}{l}\text { Organizational } \\
\text { politics, inability to } \\
\text { socialize, build } \\
\text { relationships and be } \\
\text { visible }\end{array}$ & $\begin{array}{l}\text { Unable to socialize } \\
\text { with important people. }\end{array}$ \\
\hline 19 & $\begin{array}{l}\text { Reduce teams } \\
\text { to increase } \\
\text { motivation }\end{array}$ & $\begin{array}{l}\text { Does not know } \\
\text { where demotion } \\
\text { decision is based } \\
\text { on. }\end{array}$ & Random decision & Unclear. \\
\hline 20 & $\begin{array}{l}\text { To reduce } \\
\text { workload }\end{array}$ & $\begin{array}{l}\text { To align personal } \\
\text { needs with work. }\end{array}$ & Performance. & $\begin{array}{l}\text { Demotion decision } \\
\text { unjustified. }\end{array}$ \\
\hline 21 & $\begin{array}{l}\text { Negative } \\
\text { performance } \\
\text { appraisal }\end{array}$ & $\begin{array}{l}\text { Negative } \\
\text { performance } \\
\text { appraisal used as } \\
\text { excuse to demote }\end{array}$ & $\begin{array}{l}\text { Too modest and shy. } \\
\text { Not visible enough. } \\
\text { Unjustified negative } \\
\text { performance appraisal } \\
\text { used as excuse }\end{array}$ & $\begin{array}{l}\text { Not showing off, } \\
\text { invisible. }\end{array}$ \\
\hline 22 & Unclear & $\begin{array}{l}\text { Not friends with } \\
\text { and being } \\
\text { disliked by } \\
\text { manager }\end{array}$ & $\begin{array}{l}\text { Friendships and } \\
\text { politics }\end{array}$ & $\begin{array}{l}\text { Lack of strategic } \\
\text { professional } \\
\text { relationships. }\end{array}$ \\
\hline 23 & $\begin{array}{l}\text { Organizational } \\
\text { restructuring }\end{array}$ & $\begin{array}{l}\text { Lack of network } \\
\text { due to } \\
\text { socioeconomic }\end{array}$ & $\begin{array}{l}\text { Unclear on what basis } \\
\text { demotion decisions } \\
\text { are made }\end{array}$ & $\begin{array}{l}\text { Random decision, } \\
\text { unclear on what basis } \\
\text { demotion decision was }\end{array}$ \\
\hline
\end{tabular}




\begin{tabular}{|l|l|l|l|l|}
\hline & status & made & . \\
\hline
\end{tabular}

Table 3: Frequency table

\begin{tabular}{|l|l|l|}
\hline Type of capital & Demotees & Co-workers \\
\hline Social capital & $\mathbf{2 1}$ & $\mathbf{3 1}$ \\
-relationships/friendships & 8 & 4 \\
-socializing/networking & 4 & 9 \\
-political behaviour & 1 & 11 \\
-being visible & 7 & 7 \\
\hline Human capital & $\mathbf{7}$ & $\mathbf{9}$ \\
-Personality & 3 & 5 \\
-Parental status & 1 & 2 \\
-Age & 3 & 2 \\
\hline Psychological capital & $\mathbf{1}$ & $\mathbf{1}$ \\
-Confidence & 1 & 1 \\
\hline Cultural capital & $\mathbf{3}$ & $\mathbf{1}$ \\
-Socioeconomic status/class & 2 & 0 \\
-Linguistic ability & 1 & 1 \\
\hline
\end{tabular}


Figure 1 Data Analysis Structure

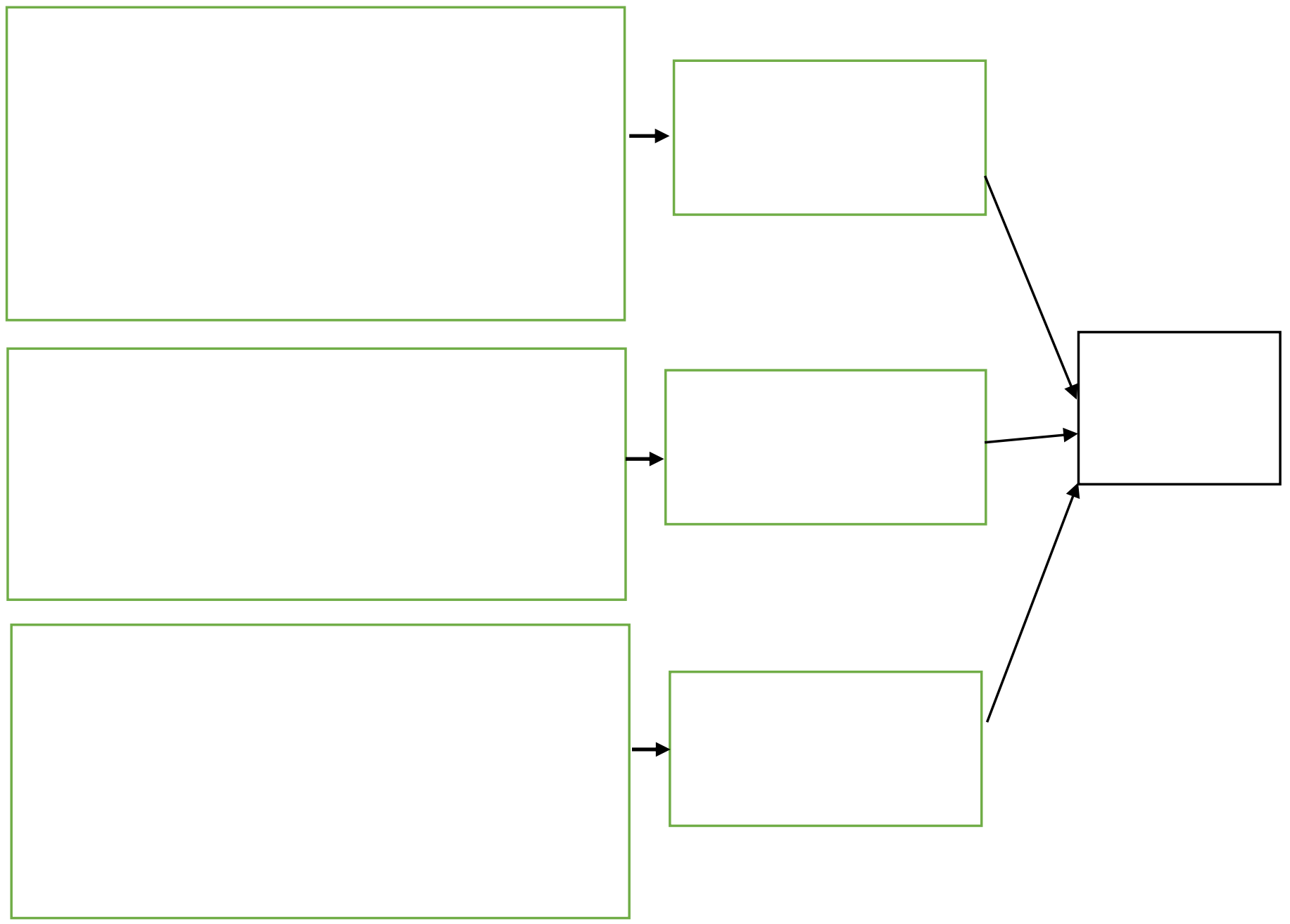

-linguistic ability and eloquence.

-personality, especially being extravert or introvert.

-socioeconomic status and social background. 
Perceptions of Demotion Decisions: A Social Capital Perspective

Figure 2 Demotees' and co-workers' perceptions of the social capital aspects of demotion decisions

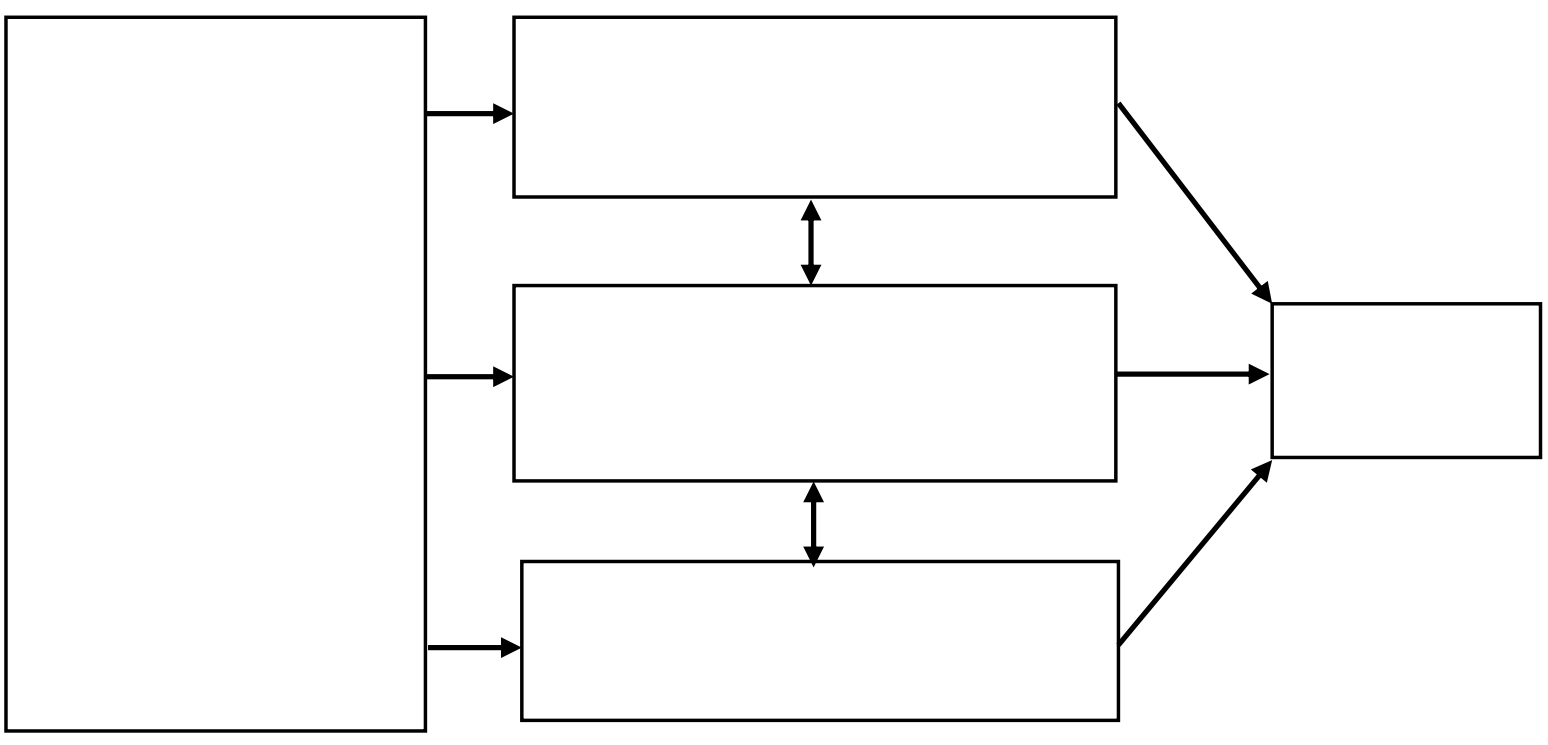

